\title{
Isolation of crude-oil-degrading Sphingomonas paucimobilis from the Persian Gulf and Caspian Sea
}

\author{
Yasaman Sanayei \\ Department of Modern and Sciences and Technologies, University of Isfahan \\ E-mail: yasaman_sanayei@yahoo.com
}

\begin{abstract}
Oil spills are a major menace to the environment because they severely damage the surrounding ecosystems. Persian Gulf in this century, Situating in the middle east, having more than 65 percent of world's oil and gas resources, having huge biodiversity and existing rich resources of pearls and shells have made this location unique and valuable. Oil and gas field wastewater or produced water is a significant waste stream in the oil and gas industries. In this study, the performance of sequencing batch reactor (SBR) and sequencing batch reactor process treating produced wastewater were investigated and compared. The SBR was operated in different hydraulic residence time (HRT) of 8, 20 and $44 \mathrm{~h}$. Operation results showed that for a HRT of $20 \mathrm{~h}$, the combined process effluent chemical oxygen demand (COD, oil removal efficiencies were 90.9 and $91.5 \%$, respectively .In this study, sequencing batch reactor(SBR) was used to treat synthetic and real produced water crude-oil-degrading Sphingomonas paucimobilis bacteria was isolated from oilcontaminated sites in the Persian Gulf and the Caspian Sea. Based on a high growth rate on crude oil and on hydrocarbon degradation ability. The combination of a SBR inoculated with a consortium of isolated halophilic microorganisms and a membrane filtration is an efficient, reliable, and compact process for organic matter produced water treatment without prior dilution.
\end{abstract}

\section{Indexing terms/Keywords}

Persian Gulf; Sphingomonas paucimobilis; oil pollution; SBR

\section{Academic Discipline And Sub-Disciplines}

Environmental Technology

\section{SUBJECT CLASSIFICATION}

Biochemistry,Biotechnology

\section{TYPE (METHOD/APPROACH)}

Experimental study and research

\section{Council for Innovative Research}

Peer Review Research Publishing System

Journal: Journal of Advances in Chemistry

Vol. 5, No. 1

editor@cirworld.com

www.cirworld.com, member.cirworld.com 


\section{INTRODUCTION}

States have the right to exploit their own natural resources but this right dose not preclude to recognize the responsibility for damages to the environment of other States. States have right to use and Exploration and Extraction their oil resources [1].Petroleum hydrocarbons are the most common environmental pollutants, and oil spills pose a great hazard to terrestrial and marine ecosystems. Oil pollution may arise either accidentally or operationally whenever oil is produced, transported, stored, processed or used at sea or on land. Oil spills are a major menace to the environment because they severely damage the surrounding ecosystems[2]. The Persian Gulf is a marine environment that was pollutedwith crude oil during the 1991 Gulf war. The pollution impact of this episode has been evaluated in several studies, all of which indicated that crude oil accumulated and remained for long time in the coastal areas[3]. The oil pollution problem is particularly acute in oil-producing areas such as the Persian Gulf, where approximately $60 \%$ of the arine-transported oil in the world is produced. The Caspian Sea is another important marine environment in Iran, although the level of oil contamination of the Caspian Sea is lower than that of the Persian Gulf, but in recent years, the level of oil pollution of the Caspian Sea has increased [4]. The growth of microorganisms on hydrocarbons presents particular problems because hydrocarbons are immiscible in water. Many bacteria are able to emulsify hydrocarbons in solution by producing surface active agents such as biosurfactants that increase the adhesion of cells to the substrate. Biosurfactants reduce the surface tension by accumulating at the interface of immiscible fluids, increasing the surface area of insoluble compounds, which

leads to increased bioavailability and subsequent biodegradation of the hydrocarbons [5]. Due to increasing volume of this waste all over the world in the current decade, the fate and effect of discharging produced water on environment has recently become a significant issue of environmental concern [6]. On the other hand, fresh water scarcity and sustainable water supply is a serious problem all over the world because of population growth and the expansion of industrial activities. This problem is a major concern in arid areas. Therefore, there is a growing impetus for sanitary and industrial wastewaters recycle and reuse [7].

The aims of the present work were to study bacterial strains isolated from oil-polluted sites in the Persian Gulf and the Caspian Sea. We evaluated the abilities of these strains to produce bioflocculating and to biodegrade crude oil.

\section{Materials and Methods}

\section{Experimental setup}

This study using Sequencing Batch Reactor. Aeration, agitation, $\mathrm{pH}$ and dissolved oxygen (DO) were controlled by the fermenter microprocessor system. Air was supplied by an air compressor. The DO concentration adjusted to $3 \mathrm{mg} \mathrm{I-1.} \mathrm{DO}$ and $\mathrm{pH}$ of the medium were monitored by the relevant probes. The agitation speed was fixed at $300 \mathrm{rpm}$. The mixed liquor was kept at a constant temperature through a shell and tube heat exchanger. Wastewater was fed to the bioreactor by using a peristaltic pump (Model Watson-101U/R, Marlow). The mixed liquor in the bioreactor was pressurized by a centrifugal pump and introduced to a crossflow membrane module (Micro 240, PCI membrane systems, UK).

\section{Wastewater composition}

The wastewater sample contained crude-oil and Sphingomonas paucimobilis bacteria.

Ten polyethylene containers of real produced water were collected from a Iran oilfield. The samples were then stored at $4^{\circ} \mathrm{C}$. All samples were thawed before feeding. Produced water characteristics of each container were analyzed in triplicate.

\section{Sampling}

For the isolation of crude-oil-degrading bacteria, sediment and sea water samples were collected from marine environments in Iran. Three collection stations were located in the Persian Gulf. Sediments samples were taken from 1 to $12 \mathrm{~cm}$ below the surface using a sterile knife. Seawater samples were collected from a depth of $15 \mathrm{~cm}$ in sterile $100-\mathrm{ml}$ bottles and transported on ice to the laboratory.

\section{Growth and crude-oil removal assay}

Sphingomonas paucimobilis Bacterial isolates were grown at $30^{\circ} \mathrm{C}$ for 1 week on rotator shaker $(180$ rpm). The growth of the isolates was routinely assessed indirectly by measuring the turbidity (OD600 nm) using a UV-visible spectrophotometer (Shimadzu UV-160, Japan). The crude oil removal assay was carried out by dissolving the residual crude-oil in the medium in dichloromethane (DCM) and reading the optical density of the oil extract against a blank at a wavelength of $420 \mathrm{~nm}$ [8].

\section{Start-up of the System}

The fermenter was filled with the real produced water that was inoculated with the isolated microorganisms ( Sphingomonas paucimobilis) and was operated batchwise with aeration and mixing for several days to obtain a MLVSS concentration of $1000 \mathrm{mg} \mathrm{l}-1$ to start with. Operation mode was 12, 24 and $48 \mathrm{~h}$ cycle. At $24 \mathrm{~h}$ mode the cycle consisted of three stages: $1 \mathrm{~h}$ of feeding time, $21 \mathrm{~h}$ of reacting time and $3 \mathrm{~h}$ of decanting time. In the last stage, $2.5 \mathrm{I}$ permeate was withdrawn from the bioreactor. 


\section{Analytical methods}

The COD of the samples ,MLSS, and MLVSS were determined according to the standard methods [9]. Also, in order to study the effect of trapped oil on MLSS and MLVSS measurement, samples were washed with methylene chloride to remove oil and then MLSS and MLVSS of the washed samples were analyzed. It was called "washed MLSS and MLVSS".

\section{Results and Discussion}

Characteristics of the synthetic produced water crude oil hydrocarbons can be divided into four classes: the saturates, the aromatics, the asphaltenes (phenols, fatty acids, ketones, esters, and porphyrins), and the resins [10]. Hydrocarbons cannot be dissolved in water; therefore, most of the oil constituents are dispersed in produced water [11] chromatogram of the raw synthetic produced water $(1 \mathrm{~mL}$ oil $/ \mathrm{L})$. Alkanes were the most abundant compounds in the synthetic produced water.

\section{MLSS, MLVSS, and oil concentration}

The MLSS concentration increased from 1560 to $7950 \mathrm{mg} / \mathrm{L}$ during 75 days (Fig. 1). MLVSS/MLSS ratio varied between 0.45 and 0.66 during the study. This typically low ratio may be due to the trapped oil between the microorganisms' flocs [12]. This conclusion may be confirmed by the observed increasing trend of trapped oil concentration in the sludge. As shown in the figure, the oil concentration in the MSBR sludge increased from $571 \mathrm{mg} / \mathrm{L}$ to $6005 \mathrm{mg} / \mathrm{L}$. The washed MLVSS/MLSS ratio of $0.65-0.76$ suggests that the accumulation of inorganic compounds of the synthetic produced water did not occur. Also, it may be concluded that most of the washed MLVSS were microorganisms.

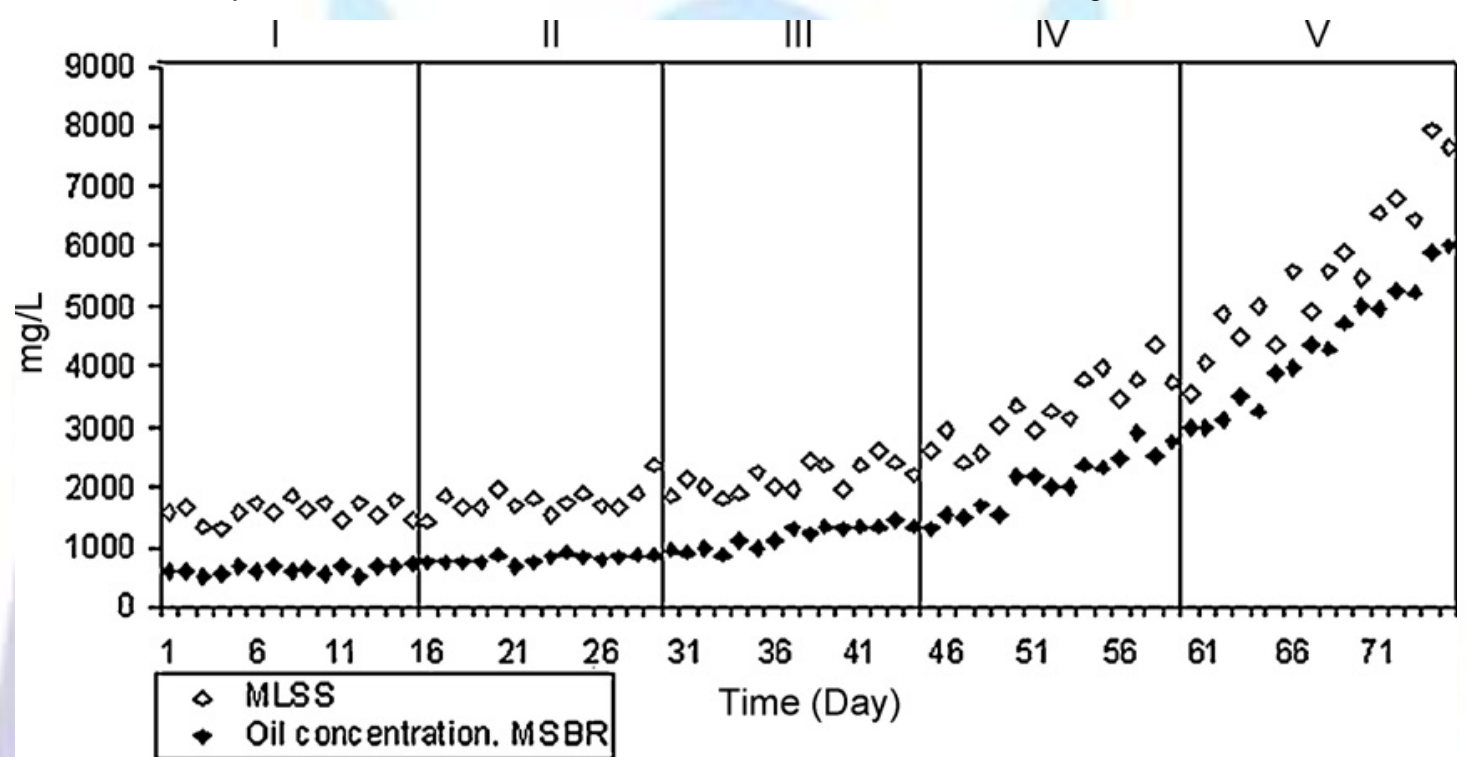

Fig .1 Variations of MLSS and oil concentration in the SBR.

\section{Influence of HRT on the removal of COD}

The bioreactor was filled with the dye wastewater that was inoculated with the isolated Sphingomonas paucimobilis and was operated batch wise with aeration and mixing for 50 days at the first run. MLSS concentration of 5,000 mg/L and Influent COD concentration of $1,000 \mathrm{mg} / \mathrm{L}$ were obtained and effect of cycle time on COD reduction was observed for three (3) cycles of 12,24 and $48 \mathrm{~h}$ duration. Figure 2 shows the effluent quality of the SBR in terms of COD. The COD varied from cycle time with a relatively large value range of between 92 and $210 \mathrm{mg} / \mathrm{L}$. However, the remaining average of the treated COD was lower than $100 \mathrm{mg} / \mathrm{L}$ at the highest cycle of $44 \mathrm{~h}$. At cycle of $20 \mathrm{~h}$ the average COD concentrations was $120 \mathrm{mg} / \mathrm{L}(88 \%)$ while at the highest cycle of $44 \mathrm{~h}$, average COD was $98 \mathrm{mg} / \mathrm{L}(90.2 \%)$. The results show a lower COD value in the treated effluent of higher reduction values was obtained with increasing of cycle. On the other hand, COD reduction is at its lowest in $12 \mathrm{~h}$ cycle. $\mathrm{Ji}$ et al. (2007) studied performance of SBR system for treating heavy oilproduced water. In their research $71-80 \%$ COD was removed from initial low COD concentration of $390 \pm 124 \mathrm{mg} / \mathrm{L}$. The effluent COD of the SBR at cycle of $44 \mathrm{~h}$ was lower than the SBR system. [13] studied the application of membranecoupled sequencing batch reactor for oilfield produced water. Their results showed a $90-92 \%$ reduction in COD at cycle of $44 \mathrm{~h}$.

The results showed that higher HRT affected oil concentration in the MSBR. During cycle time of 24 and $12 \mathrm{~h}$, increased accumulation of crude oil was observed up to $2110 \mathrm{mg} / \mathrm{L}$. This trend was severe at cycle time of $12 \mathrm{~h}$. At the lowest HRT, the 


\section{Conclusions}

A lab-scale cross flow sequencing batch reactor inoculated with isolated microorganisms was used effectively for oilfield produced water treatment. It was found that the isolated microorganisms played an important role in the biodegradation of the pollutants. It was thus feasible to treat the produced water using the SBR and the product quality met the requirements for discharge and reuse. Effect of cycle time on COD reduction was observed for three different SBR cycle (12, 24 and 48 $\mathrm{h}$ duration). Although the produced water is a complex mixture of different contaminations, but, by using suitable and effective technologies it can be treated for various reclamation and reuse alternative options.

\section{REFERENCES}

[1] Fakhru'l-Razi, A., Pendashteh, A.R., Luqman Chuah, A., Dayang Radiah, A.B., Madaeni, S.S., Zurina, Z.A., (2009),"Review of technologies for oil and gas produced water treatment". J.Hazard. Mater 170: 530-551.

[2] Head, I.M., Jones, D.M., Roling, W.F,(2006)"Marine microorganisms make a meal of oil”. Nat. Rev. Microbiol. 4: 173182.

[3] Hassanshahian, M., Emtiazi, G., Kermanshahi, R., Cappello, S., (2010), "Comparison of oil degrading microbial communities in sediments from the Persian Gulf and Caspian Sea , Soil Sediment" . Contam 19: 277-291.

[4] Radwan, S.S., Al-Hasan, R.H., Salamah, A., Khanafer, M., (2005) ,"Oil-consuming microbial consortia floating in the Persian Gulf'. Int. Biodeter. Biodegrad 56.

[5] Batista, S.B., Mounteer, A., Amorim, F.R., Totola, M.R., (2006), "Isolation and characterization of biosurfactant/bioemulsifier-producing bacteria" Bioresour. Technol. 85: 257-261.

[6] Tellez, G.T., Nirmalakhandan, N., Gardea-Torresdey, J., (2002),"Performance evaluation of an activated sludge system for removing petroleum hydrocarbons from oilfield produced water". Adv. Environ. Res. 6;455-470.

[7] Choi, J.G., Bae, T.H., Kim, J.H., Tak, T. M., Randall, A.A., (2002)," The behavior of membrane fouling initiation on the crossflow membrane bioreactor system". J. Membr. Sci 203:103-113.

[8] Rahman, K.S.M., Thahira-Rahman, J., Lakshmanaperumalsamy, P., Banat, I.M.,. (2004),"Towards efficient crude oil degradation by a mixed bacterial consortium. petroleum contaminated sites". Bioresour. Technol 97: 868-875

[9] APHA, AWWA, WEF., "Standard Methods for Examination of Water and Wastewater" (2005), 21th ed. American Public Health Association, Washington, DC:

[10] Leahy, J.G., Colwell, R.R., (1990)," Microbial degradation of hydrocarbons in the environment”. Microbiol. Mol. Biol. Res 53: 305-315.

[11] Ekins, P., Vanner, R., Firebrace, J., (2007)," Zero emissions of oil in water from offshore oil and gas installations: economic and environmental implications". J. Clean Prod. 15: 1302-1315.

[12] Freire, D.D.C., Commarota, M.C.C., Sant'anna Jr., G.L., (2001 "Biological treatment of oilfield produced water in a sequencing batch reactor". Environ. Technol 22):1125-1135.

[13] Fakhru'l-Razi, A., Pendashteh, A.R., Zurina, Z.A., Luqman Chuah, A., Dayang Radiah, A.B., Madaeni, S.S., (2010) "Application of membrane-coupled sequencing batch reactor for oilfield produced water recycle and beneficial reuse". Bioresour.Technol 101: 6942-6949.

\section{Author' biography with Photo}

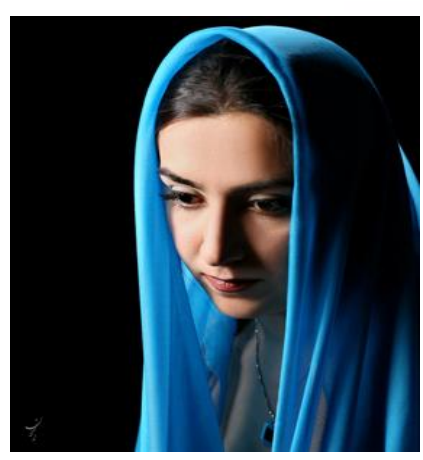

Yasaman Sanayei , Ph.D. is currently Asistant Professor University of Isfahan ,Dr. Yasaman Sanayei has been a practicing professional in various areas of environmental science and technology with particular emphasis on water quality, and treatability studies in relation to water, wastewater and analytical testing. She actively involved in the technical aspects of biological and biological treatment in dye wastewater, bioremediation research, environmental analytical techniques, sampling and data validation. Dr Yasaman Sanayei involved in research project on wastewater treatment and acclimatization studies for a semiconductor industry and bioflocculant production for water 